\title{
Hemoglobin Corrected Diffusion Capacity of the Lung for Carbon Monoxide
}

National Cancer Institute

\section{Source}

National Cancer Institute. Hemoglobin Corrected Diffusion Capacity of the Lung for

Carbon Monoxide. NCI Thesaurus. Code C120825.

An assessment of the diffusion capacity of the lungs for carbon monoxide adjusted for hemoglobin concentration. 